\title{
Konsep Wahyu Memandu Ilmu sebagai Paradigma Keilmuan UIN Sunan Gunung Djati
}

\author{
Wawan Ridwan' ${ }^{1}$, Nanat Fatah Natsir ${ }^{2}$, Erni Haryanti ${ }^{3}$ \\ 1,2,3Universitas Islam Negeri Sunan Gunung Djati Bandung, Indonesia \\ E-mail: cikajangridwan@gmail.com, nanatfatahnatsir@uinsgd.ac.id, erni hk@uinsgd.ac.id
}

\begin{abstract}
Article Info
Article History

Received: 2021-11-20

Revised: 2021-12-15

Published: 2022-01-09
\end{abstract}

Keywords:

Concept;

Revelation;

Knowledge;

Paradigm;

UIN Sunan Gunung Djati.

\begin{abstract}
This study describes the concept of revelation guiding science as a scientific paradigm at UIN Sunan Gunung Djati. The method used in this study uses a library research method or approach, that library research can be interpreted as a series of activities related to the methods of collecting library data, reading and taking notes and processing research materials. The results of this study indicate that UIN Sunan Gunung Djati Bandung (abbreviated as UIN Bandung) carries a clear and distinct vision from other universities. The UIN campus also continues to strive to improve management and technology as a mainstay feature to achieve higher education quality. This institution uses the WMI (Wahyu Menandu Ilmu) paradigm as its philosophical foundation, making the vision of UIN Bandung very distinctive compared to others. Consider the following vision of UIN Bandung: To be a State Islamic University that is Superior and Competitive Based on Revelation, Guiding Science in the Frame of Akhlak Karimah in ASEAN in 2025. With this vision, the scientific paradigm of UIN Bandung and the policy of developing higher education are integrated with revealed values (religion), which is something that is not partial or dichotomous. The WMI paradigm is thus not only a basis in determining the direction and policies of the institution but becomes a guideline for the implementation of Higher Education. In the academic realm where the core business is providing education, this paradigm becomes a reference in personality formation and the development of scientific disciplines.
\end{abstract}

\begin{tabular}{l}
\hline Artikel Info \\
\hline Sejarah Artikel \\
Diterima: $2021-11-20$ \\
Direvisi: $2021-12-15$ \\
Dipublikasi: $2022-01-09$
\end{tabular}

Kata kunci:

Konsep;

Wahyu;

Ilmu;

Paradigma;

UIN Sunan Gunung Djati.

\section{PENDAHULUAN}

Integrasi keilmuan merupakan sebuah konsep pola pendidikan dan pengajaran yang holistik sehingga menimbulkan kesadaran dalam diri para penuntut ilmu dalam hal keterkaitan antara ilmu pengetahuan dengan ketuhanan, keberagamaan, kebermoralan, kemanusiaan, serta peran
Penelitian ini menjelaskan tentang konsep wahyu memandu ilmu sebagai paradigma keilmuan UIN Sunan Gunung Djati. Metode yang digunakan dalam kajian ini menggunakan metode atau pendekatan kepustakaan (library research), bahwa studi pustaka atau kepustakaan dapat diartikan sebagai serangkaian kegiatan yang berkenaan dengan metode pengumpulan data pustaka, membaca dan mencatat serta mengolah bahan penelitian. Hasil penelitian ini menunjukkan bahwa UIN Sunan Gunung Djati Bandung (disingkat UIN Bandung) mengusung visi yang jelas dan pasti berbeda (distinct) dengan Perguruan Tinggi yang lain. Kampus UIN juga terus berupaya meningkatkan manajemen dan teknologi sebagai fitur andalan untuk mencapai kualitas Perguruan Tinggi. Institusi ini menggunakan paradigma WMI (Wahyu Memandu Ilmu) sebagai landasan filofisnya, menjadikan visi UIN Bandung menjadi sangat khas dibandingkan dengan yang lain. Perhatikan visi UIN Bandung berikut: Menjadi Universitas Islam Negeri yang Unggul dan Kompetitif Berbasis Wahyu Memandu Ilmu dalam Bingkai Akhlak Karimah di ASEAN tahun 2025. Dengan visi ini, paradigma keilmuan UIN Bandung dan kebijakan pengembangn Perguruan Tinggi bersifat terintegrasi dengan nilai-nilai wahyu (agama), yakni sesuatu yang tidak bersifat parsial atau dikotomis. Paradigma WMI dengan demikian bukan sekedar landasan dalam menetukan arah dan kebijakan lembaga tetapi menjadi pedoman penyelenggaraan Perguruan Tinggi. Pada ranah akademik dimana core bussines-nya menyelenggarakan pendidikan, paradigma tersebut menjadi acuan dalam pembentukan kepribadian dan pengembangan disiplin ilmu. manusia sebagai khalifah di muka bumi, serta tujuan yang dirancang Tuhan dari penciptaannya. Hal ini sangat menentukan maju tidaknya suatu umat atau suatu bangsa negara. Di kota Bandung Jawa Barat, DIY Yogyakarta, Ibu Kota Jakarta, Medan Sumatera Utara, Malang Jawa Timur misalnya merupakan kota-kota metropo- 
litan di mana geliat keilmuan, khusus universitas Islam dan sekolah tinggi Islam sudah banyak didirikan dan berperan dalam mencerdaskan masyarakat muslim.

Penelitian yang dilakukan oleh (Simamora, 2016) yang dilatarbelakangi oleh asumsi yang telah adanya upaya atau pemikiran untuk mengintegrasikan keilmuan dalam rancangan dan pemikiran para pendiri universitas Islam tersebut, meskipun berbeda konsep dan tingkatannya. Secara teoritis bagaimana sejarah dan perkembangan integrasi keilmuan sepanjang sejarah peradaban Islam, dan sudah sampai di mana upaya-upaya yang diterapkan oleh para pengelola perguruan tinggi Islam di Indonesia. Hasil Peneliti tersebut temukan bahwa semua universitas Islam maupun sekolah tinggi Islam telah melakukan upaya-upaya integrasi keilmuan dengan bentuk dan tingkatan yang berbeda-beda.

Universitas Islam Negeri Sunan Gunung Djati Bandung misalnya, upaya-upaya integrasi yang telah diterapkan di sana terletak pada bagaimana memadukan ilmu agama dan ilmu umum yang selama ini dikotomis, penyelenggaraan seminar dan workshop tentang integrasi keilmuan baik di kalangan Dosen, pegawai administrasi, pembenahan kontens dari mata kuliah dengan prinsipprinsip ajaran Islam, studi banding ke universitas Islam yang telah menerapkan sebuah model integrasi. Begitu juga dengan kampus-kampus swasta lainnya, mereka melakukan upaya integrasi melalui pelatihan atau semacam workhop implementasi integrasi sains dan nilai keislaman kedalam kurikulum perguruan tinggi masing-masing yang ada di jawa barat khususnya seputar kota Bandung, pelaksanaan integrasi pengetahuan ini diwujudkan dalam perluasan beberapa fakultas dan program studi melalui penambahan fakultas sekuler dan departemen, dan reposisi dari departemen yang ada dalam studi Islam. Implementasi ini juga dapat dilihat pada pergeseran kurikulum baru yang mengadopsi kedalam ilmu alam, ilmu sosial, dan humaniora.

Proses integrasi pengetahuan telah dibentuk oleh respon internal dan eksternal yang dinamis baik untuk kepentingan guna mendorong ataupun menghambat proses. Menurut (Irwansyah, 2021) bahwa proses pembentukan pengetahuan merupakan hasil daripada kebiasaan yang dibentuk dalam waktu yang panjang, sehingga menjadi sebuah budaya, Pokok permasalahan yang akan dibahas dalam penelitian ini yaitu bagaimana konsep dan implementasi Paradigma Integrasi Keilmuan Universitas Islam Negeri
(UIN) Sunan gunung Djati Bandung. Di mana rumusan umum tersebut diuraikan menjadi beberapa rumusan terperinci tentang karakteristik konsepsi integrasi keilmuan yang dibangun oleh UIN Sunan Gunung Djati Bandung; dan bagaimana Kontekstualisasinya terhadap Perkembangan Pendidikan di Indonesia.

\section{METODE PENELITIAN}

Sesuai dengan karakteristik masalah yang diangkat dalam penelitan ini maka menggunakan Metode Riset kualitatif, yaitu menekankan analisanya pada data deskriptif berupa kata-kata tertulis yang diamati. Pendekatan kualitatif penulis gunakan untuk menganalisis kajian konsep wahyu memandu ilmu sebagai paradigma keilmuan UIN Sunan Gunung Djati, maka dengan sendirinya penganalisaan data ini lebih difokuskan pada Penelitian Kepustakaan (Library Research), yakni dengan membaca, menelaah dan mengkaji buku-buku dan sumber tulisan yang erat kaitannya dengan masalah yang dibahas. Metode yang digunakan dalam kajian ini menggunakan metode atau pendekatan kepustakaan (library research), menurut Zed dalam (Rahayu, 2020) bahwa studi pustaka atau kepustakaan dapat diartikan sebagai serangkaian kegiatan yang berkenaan dengan metode pengumpulan data pustaka, membaca dan mencatat serta mengolah bahan penelitian.

Jenis penelitian ini adalah penelitian kualitatif. Menurut Ibnu dalam (Nasser, 2021) penelitian kualitatif adalah suatu penelitian yang datanya dinyatakan dalam bentuk verbal dan dianalisis tanpa menggunakan teknik statistik. Berdasarkan beberapa definisi penelitian kualitatif di atas, dapat disimpulkan bahwa penelitian kualitatif adalah suatu penelitian yang datanya dinyatakan dalam bentuk verbal, tidak menggunakan angka dan analisisnya tanpa menggunakan teknik statistik.

1. Objek Penelitian

Dalam penelitian ini objek penelitian terdiri dari 2 (dua), yaitu objek formal dan objek material (Arifudin, 2019). Objek formal dalam penelitian ini berupa data yaitu data yang berhubungan dengan tinjauan konsep wahyu memandu ilmu sebagai paradigma keilmuan UIN Sunan Gunung Djati. Sedangkan objek materialnya berupa sumber data, dalam hal ini adalah tinjauan kritis terhadap konsep wahyu memandu ilmu sebagai paradigma keilmuan UIN Sunan Gunung Djati. 
2. Waktu Penelitian

Penelitian ini dilaksanakan pada bulan November sampai dengan Desember tahun 2021.

3. Teknik Pengumpulan Data

Pengumpulan data yang dilakukan dengan menggunakan teknik dokumentasi yaitu mengadakan survey bahan kepustakaan untuk mengumpulkan bahan-bahan, dan studi literatur yakni mempelajari bahan-bahan yang berkaitan dengan objek penelitian. Teknik pengumpulan data menurut (Bahri, 2021) mengemukakan bahwa merupakan langkah yang paling strategis dalam penelitian karena tujuan untama dari penelitian adalah mendapatkan data. Terdapat beberapa cara atau teknik dalam mengumpulkan data, diantaranya adalah observasi dan dokumentasi. Sumber data yang digunakan dalam penelitian ini mencakup data primer dan sekunder. Menurut (Hanafiah, 2021) bahwa data primer adalah data yang dikumpulkan langsung dari individu-individu yang diselidiki atau data tangan pertama. Sedangkan data sekunder adalah data yang ada dalam pustaka-pustaka. Data primer dalam penelitian ini adalah buku-buku terkait konsep wahyu memandu ilmu sebagai paradigma keilmuan UIN Sunan Gunung Djati, dan data sekunder didapatkan dari jurnal-jurnal baik nasional maupun internasional.

4. Alat Pengumpulan Data

Dalam penelitian ini, penulis akan menggunakan metode dokumentasi sebagai alat untuk pengumpul data karena penelitian ini adalah penelitian kepustakaan. Dengan kata lain, menurut (Juhji, 2020) bahwa teknik ini digunakan untuk menghimpun data-data dari sumber primer maupun sekunder.

5. Teknik Analisis Data

Analisis data tidak saja dilakukan setelah data terkumpul, tetapi sejak tahap pengumpulan data proses analisis telah dilakukan. Penulis menggunakan strategi analisis "kualitatif", strategi ini dimaksudkan bahwa analisis bertolak dari data-data dan bermuara pada kesimpulan-kesimpulan umum. Berdasarkan pada strategi analisis data ini, dalam rangka membentuk kesimpulan-kesimpulan umum analisis dapat dilakukan menggunakan kerangka pikir "induktif". Menurut (Sugiyono, 2015) bahwa metode pembahasan menggunakan metode deskriptif-analisis, yaitu menjelaskan serta mengelaborasi ide-ide utama yang berkenaan dengan topik yang dibahas. Kemudian menyajikannya secara kritis melalui sumber- sumber pustaka primer maupun skunder yang berkaitan dengan tema.

6. Prosedur Penelitian

Data pada penelitian ini dicatat, dipilih dan kemudian diklasifikasikan sesuai dengan kategori yang ada. Pendekatan yang digunakan adalah pendekatan deskriptif analitis. Menurut (Marantika, 2020) bahwa deskriptif analitis (descriptive of analyze research), yaitu pencarian berupa fakta, hasil dari ide pemikiran seseorang melalui cara mencari, menganalisis, membuat interpretasi serta melakukan generalisasi terhadap hasil penelitian yang dilakukan. Prosedur penelitian ini adalah untuk menghasilkan data deskriptif yang berupa data tertulis setelah melakukan analisis pemikiran (content analyze) dari suatu teks. Setelah penulis mengumpulkan bahan-bahan yang berhubungan dengan masalah yang akan di bahas dalam penelitian ini, kemudian penulis menganalisis dan menarasikan untuk diambil kesimpulan.

\section{HASIL DAN PEMBAHASAN}

Dalam pembahasan ini akan dibahas tentang Paradigma Pendidikan Islam, dan Konsep Integrasi Keilmuan UIN di Indonesia.

1. Paradigma Pendidikan Islam

Paradigma jika dikaitkan kedalam disiplin intelektual merupakan cara pandang orang terhadap diri dan lingkungannya yang akan mempengaruhinya baik dalam berpikir dan bersikap, serta bertingkah laku. Robert Friedrichs dalam (Na'im, 2021) berpendapat bahwa Paradigma yaitu sekumpulan tata nilai yang membentuk pola pikir seseorang sebagai titik tolak pandangannya dan membentuk citra subjektif seseorang terhadap realita yang ada sehingga dapat menentukan cara menangani kenyataan atau realita tersebut. Dasar dari paradigma pendidikan Islam adalah alQur'an dan al-Sunnah yang digunakan sebagai rujukan utama dalam membuat dan mengembangkan konsep, prinsip, teori, dan teknik pendidikan. Dapat disimpulkan bahwa ideologi atau paradigma pendidikan merupakan gambaran utuh antara ketauhidan, akhlak, alam semesta dan tentang manusia yang dikaitkan dengan teori pendidikan Islam. Secara historis, pendidikan benar-benar telah mampu membangun sebuah peradaban, sehingga adanya sebuah paradigma pendidikan Islam yang merupakan sebuah keniscayaan (Bashori, 2017). 
Paradigma Pendidikan Islam adalah pandangan menyeluruh yang mendasari rancang bangun suatu sistem pendidikan (Nasrudin, 2008). Pada saat ini dalam memahami paradigma pendidikan Islam, maka kata yang tersirat adalah pendidikan yang bercirikan khas Islam sehingga mengindikasikan konsep pendidikan yang secara akurat bersumber pada ajaran Islam. Ilmu pendidikan Islam didasarkan pada konsep dan teori yang dikembangkan dari nilai-nilai Islam yaitu alQur'an dan as-Sunnah dan ijtihad (Roqib, 2009). Di samping itu, hakikat pendidikan islam yaitu suatu proses untuk mencapai tujuan bahwa manusia di dunia ini adalah hanya menjalankan amanah Allah SWT dalam arti beribadah kepadaNya. Hal tersebut sejalan dengan firman Allah dalam surat Q.S. al-Dzariyat ayat 56 yang artinya "Dan aku tidak menciptakan jin dan manusia melainkan supaya mereka mengabdi kepada-Ku)".

Pendidikan dan pendidikan Islam khususnya menjadi perhatian dalam kehidupan individu, masyarakat baik berbangsa dan bernegara. Pendidikan yang baik dan maju turut menentukan majunya suatu bangsa (Hasbi, 2021). Sebaliknya, bangsa yang mundur adalah wujud dari mundurnya pendidikan yang ada pada bangsa itu sendiri. Pendidikan merupakan proses seseorang mengembangkan kemampuan sikap dan tingkah laku di dalam masyarakat tempat ia hidup, juga pendidikan itu adalah proses sosial yang terjadi pada orang yang dihadapkan pada pengaruh lingkungan yang terpilih dan terkontrol (khususnya yang datang dari sekolah), sehingga mereka dapat memperoleh pengembangan kemampuan sosial dan kemampuan individu yang optimal (Fattah, 2008).

\section{Konsep Integrasi Keilmuan UIN di Indonesia}

Istilah integrasi berasal dari kata to integrate yang secara leksikal berarti combine or something so that it becomes fully a part of somethings else. Jika diartikan sebagai kata benda, maka integrasi atau integration berarti mix or be together as one group (Manser, 1991), pada intinya jadi integrasi dapat dimaknai menyatupadukan, menggabungkan, mempersatukan dua hal atau lebih menjadi satu. Integrasi berasal dari bahasa Inggris integration yang memiliki arti kesempurnaan atau keseluruhan. Integrasi ilmu dimaknai sebagai sebuah proses menyempurnakan atau menya- tukan keilmuan yang selama ini dianggap dikotomis sehingga menghasilkan satu pola pemahaman yang integrative tentang konsep ilmu pengetahuan. Bagi Kuntowijoyo, inti dari integrasi yaitu sebuah upaya menyatukan, bukan sekedar menggabungkan saja antara wahyu Tuhan dan temuan manusia atau ilmuilmu integralistik, tidak mengucilkan Tuhan atau sekularisme atau bahkan mengucilkan manusia other worldly asceticism (Kuntowijoyo., 2006). Definisi lainnya Integrasi yaitu menjadikan al-Qur'an dan al-Sunnah sebagai grand theory ilmu pengetahuan, sehingga ayat-ayat Qauliyah dan kauniyah-nya dapat digunakan (Suprayogo, 2005).

Disertasi (Tabroni, 2017) menemukan bahwa Pendidikan dalam hal ini berkaitan dengan sanksi yang ada di dunia Pendidikan, khususnya pendidikan di Pondok Pesantren, beliau menjelaskan bahwa pertama, dalam sanksi di Pesantren merupakan hukuman yang telah disepakati oleh pihak pesantren bagi santri yang telah melanggar tata tertib dengan tujuan agar mereka tidak mengulangi lagi perbuatan serupa (mendidik), kedua, Jenis pelanggaran diantaranya pelanggaran ringan, sedang, berat, dan volume. Pelaksana sanksi hanyalah boleh dilakukan oleh para pengurus, ustadz, dan kiai, ketiga; sanksi di tiga pesantren ini efektif untuk mengubah perilaku santri, keempat pandangan dari pihak pesantren, santri, orang tua, dan masyarakat mengenai sanksi di pondok pesantren ialah baik dan efektif untuk memberikan efek jera kepada santri yang melanggar, berbeda dengan KPAI dan Komnas HAM, kelima; rumusan konsep model sanksi dalam perspektif pendidikan Islam ialah hukuman psikis dan fisik yang ditetapkan oleh pihak pesantren bagi santri yang melanggar dengan tetap memperhatikan prinsip pendidikan Islam. Teknik pelaksanaan atas sanksinya sebagai berikut: menentukan jenis pelanggaran pertama; pengaruh negatif pola asuh orang tua dan lingkungan pergaulan anak, bentuk sanksi berupa psikis; memberikan keteladanan dengan sifat kasih sayang dan lemah lembut sesuai dengan prinsip pendidikan Islam, jenis pelanggaran kedua; melihat tipologi santri, bentuk sanksi; mengarahkan, menyindir, memberi petunjuk, memberi teguran, memberi seruan, jenis pelanggaran ketiga; melihat motif pelanggaran; bentuk sanksi; sama dengan kedua. 
Perguruan Tinggi (PT) dalam konteks Peguruan Tinggi Keagamaan Islam mempunyai kekhasannya (distinction) masing-masing. PTKI bisa berkembang menjadi institusi yang membawa kekhasan agama dan ilmu pengetahuan. Menurut (Arifudin, 2021) bahwa kekhasan sebuah PT yang paling mudah dapat dilihat dari visi dan misi yang diusungnya. Visi dan misi dirumuskan dengan melihat realitas masa sekarang dan meneropong kebutuhan masa dating, diantaranya UIN Sunan Gunung Djati Bandung dengan konsep Wahyu Memandu Ilmu nya, dimana Roda Pedati atau wahyu memandu ilmu UIN Bandung. Lebih jauh dari itu, visi dan misi dibuat dengan menggunakan landasan filosofis tentang keaadan ideal yang diharapkan pada masa depan. UIN Sunan Gunung Djati Bandung (disingkat UIN Bandung) mengusung visi yang jelas dan pasti berbeda (distinct) dengan PT yang lain. Kampus UIN juga terus berupaya meningkatkan manajemen dan teknologi sebagai fitur andalan untuk mencapai kualitas PT (Darmalaksana, 2019).

Institusi ini menggunakan paradigma WMI (Wahyu Memandu Ilmu) sebagai landasan filofisnya, menjadikan visi UIN Bandung menjadi sangat khas dibandingkan dengan yang lain. Perhatikan visi UIN Bandung berikut: Menjadi Universitas Islam Negeri yang Unggul dan Kompetitif Berbasis Wahyu Memandu Ilmu dalam Bingkai Akhlak Karimah di ASEAN tahun 2025. Dengan visi ini, paradigma keilmuan UIN Bandung dan kebijakan pengembangan Perguruan Tinggi bersifat terintegrasi dengan nilai-nilai wahyu (agama), yakni sesuatu yang tidak bersifat parsial atau dikotomis. Paradigma WMI dengan demikian bukan sekedar landasan dalam menetukan arah dan kebijakan lembaga tetapi menjadi pedoman penyelenggaraan PT. Pada ranah akademik dimana core bussines-nya menyelenggarakan pendidikan, paradigma tersebut menjadi acuan dalam pembentukan kepribadian dan pengembangan disiplin ilmu (Irawan, 2019).

Hal ini sebagaimana dikatakan oleh (Natsir, 2013) Paradigma Wahyu Memandu Ilmu dalam Pembidangan Ilmu-Ilmu Keislaman. Natsir berusaha memadukan ilmu agama dan ilmu umum yang selama ini dikotomis. Hal ini disinggung dalam al-Qur'an surat Ali Imran ayat 190-191 yang artinya: "Sesungguhnya dalam penciptaan langit dan bumi dan silih bergantinya malam dan siang terdapat tanda- tanda bagi orang-orang yang berakal, yaitu orang-orang yang mengingat Allah sambil berdiri atau duduk atau dalam keadaaan berbaring dan mereka memikirkan tentang penciptaan langit dan bumi seraya berkata: Ya Tuhan kami, tidaklah Engkau menciptakan ini dengan sia-sia, Mahasuci Engkau, maka peliharalah kami dari siksa api neraka" (QS. Ali Imran ayat 190-191).

Ayat al-Qur'an lainnya berbunyi yang artinya Dan Aku tidak menciptakan Jin dan Manusia melainkan supaya menyembah-Ku (QS al-Dzariyat ayat 56) harus menjadi pedoman bagi orang-orang yang berakal dalam mengamati dan menganalisis sebuah fenomena alam beserta isinya sebagai ciptaan Allah untuk dimanfaatkan oleh manusia sekaligus dijadikan sebagai media untuk mengabdikan diri kepada-Nya.

Dalam upaya integrasi ilmu agama dan ilmu umum UIN Sunan Gunung Djati Bandung, Prof Nanat mengilustrasikannya dalam "filosofi atau metafora RODA" berikut ini: Ilustrasi filosofi RODA ini menandakan adanya titiktitik persentuhan, antara ilmu dan agama. Artinya, pada titik-titik persentuhan itu, kita dapat membangun juga kemungkinan melakukan integrasi keduanya. Bagaimana pula dengan pandangan mengenai ilmu. Dalam teori ilmu (theory of knowledge), suatu pembagian yang amat populer untuk memahami ilmu adalah pembagian bahasan secara ontologi, epistemologi, dan aksiologi. Maka lokus pandangan keilmuan UIN Sunan Gunung Djati Bandung yang utuh itu dibingkai dalam metafora sebuah roda. Roda adalah simbol dinamika dunia ilmu yang memiliki daya berputar pada porosnya dan berjalan melewati relung permukaan bumi.

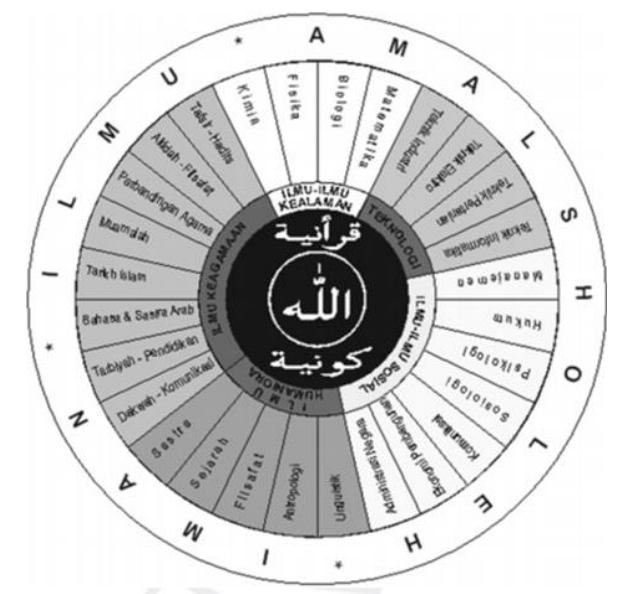

Gambar 1. Metafora Roda Wahyu Memandu Ilmu. Sumber: (Konsorium 2018) 
Penjelasan dari metafora diatas adalah Wahyu yang besumber dari Allah Swt adalah titik awal yang berfungsi memandu ilmu dan sebagai titik akhir dari ilmu yang dipandu oleh wahyu. Logika dari memandu dan dipandu secara metaforis ini dinisbatkan pada fungsi sebuah roda sebagai pengendali bagi si pengemudi atau dalam hal ini ilmuwan Pendidikan, kemudian penyalur atau tenaga yang dalam hal ini adalah ilmu. Kemudian metaforis dari penopang dari kendaraan atau dalam hal ini akal, indera dan intuisi. Selanjutnya penyerap atau tekanan dari permukaan jalan (dunia empiris/alam semesta yang ditangkap oleh akal, indera dan intuisi).

Fungsi roda dalam sebuah kendaraan ini diibaratkan fungsi UIN Bandung pada masa mendatang yang mampu menjadi sarana dalam integrasi antara ilmu dan agama dalam konstalasi perkembangan budaya, tradisi, teknologi dan pembangunan bangsa sebagai tanggungjawab yang diembannya. Kekuatan roda keilmuan UIN Bandung ini dapat memacu kreativitas untuk melihat kitab suci sebagai sumber ilham keilmuan yang relevan dengan bidang kehidupan secara dinamis. Karenanya, agar ilmu dan agama mampu selalu mentransendesi dirinya dalam upaya memajukan keluhuran budaya, kelestarian tradisi, penguasaan teknologi dan pembangunan bangsa seiring dengan perubahan global dalam kerangka memenuhi kepentingan kognitif dan praktis dari keduanya.

Metafora roda sebagai komponen vital sebuah kendaraan melambangkan kesatuan utuh dan unsur-unsur yang paralel saling menguatkan dan menserasikan. Secara fisik sebuah roda adalah bagian as (poros), velg (dengan jari-jannya) dan ban luar (ban karet). Tiga bagian ini bekerja simultan dalam kesatuan yang harmonis, yakni tata kerja roda. Fungsi roda sebagai penopang beban memiliki cara kerja yang unik yang paralel saling menguatkan dan menserasikan. Ketika roda itu berputar, maka komponen-komponen yang melekat padanya ikut bekerja sesuai dengan fungsinya. Jika dihampiri ilustrasi itu antara ilmu dan agama dengan berbagai cara pendekatan dan pandangan, tampak tidak saling menafikan, melainkan bisa saling mengoreksi dan memperkaya. Metafora filosofi pengembangan sistem kerja dan semangat akademik UIN Sunan Gunung Djati Bandung di masa depan mengacu pada rincian "Filosofi Roda" ini sebagai berikut :
Pertama, as atau poros roda melambangkan titik sentral kekuatan akal budi manusia yang bersumber dan nilai-nilai ilahiyah, yaitu Allah sebagai sumber dari segala sumber. Titik sentral ini mencerminkan pusat pancaran nilai-nilai keutamaan yang berasal dari pemilik-Nya (Allah Swt), sekaligus titik tujuan seluruh ikhtiar manusia. Dengan kata lain tauhidullah sebagai pondasi pengembangan seluruh ilmu. Sebab itu, ibarat gaya sentrifugal (gaya dari dalam menuju luar) yang terdapat dalam putaran roda, pancaran semangat inilah yang di isi nilai-nilai ilahiyah menjadi sumbu kekuatan utama dalam proses integrasi keilmuan UIN. Dari titik inilah paradigma keilmuan UIN berasal, meskipun dalam perkembangannya dalam dunia ilmu ternyata tak sepenuhnya ditentukan oleh argumentasiargumentasi logis, tetapi banyak pula dipengaruhi unsur sosiologis dan psikologis dengan menampakkan keragaman bentuk yang berbeda dan problematik.

Poros roda melambangkan titik inti pencapaian tujuan akhir. Ibarat gaya sentripetal (gaya dari luar menuju dalam) pada sebuah roda yang berputar, mencerminkan identitas keilmuan UIN Sunan Gunung Djati Bandung yang dinamik pada derajat kedalaman tertentu merupakan hasil pengujian dengan kebenaran hakikinya yang lebih komprehensif dan menyentuh inti kehidupan yang bersumberkan pada nilai-nilai ilahiyah. Kurikulum yang dikembangkan ke arah penemuan (invention) dan pewarisan (discovery) khazanah keislaman merupakan hakikat ilmu pengetahuan dalam upaya integrasi keilmuan UIN Sunan Gunung Djati Bandung. Karena itu, poros roda melambangkan titik awal sekaligus titik akhir dari upaya integrasi keilmuan UIN Sunan Gunung Djati Bandung. Proses integrasi keilmuan UIN Sunan Gunung Djati Bandung mengedepankan corak nalar rasional dalam menggali khazanah ilmu pengetahuan Islam yang bersumber langsung dan wahyu untuk menciptakan hasil kreasi ilmu Islami yang kontemporer, dan corak berfikir kritis dan selektif terhadap ilmu pengetahuan kontemporer yang berkembang untuk menemukan benang emas ilmu pengetahuan dan teknologi dengan nilai-nilai yang Islami. Dengan demikian ayat-ayat qur'aniyyah dan ayat-ayat kawniyyah sebagai sumber ilmu yang terintegrasi dan holistik yang kedua-duanya bersumber dari Allah Swt sebagai sumber segala sumber kebenaran yang sejati. Dua corak ini 
ditamsilkan sebagai gaya dalam putaran sebuah roda yang berasal dari dan menuju ke porosnya.

Kedua, velg roda yang terdiri dari sejumlah jari-jari, lingkaran bagian dalam dan lingkaran luar melambangkan rumpun ilmu dengan beragam jenis disiplin yang berkembang saat ini. Setiap ilmu memiliki karakteristiknya masing-masing yang memudahkan kita untuk membedakan satu dengan yang lainnya. Tetapi dalam perbedaan itu terdapat fungsi yang sama, yakni ilmu sebagai alat untuk memahami hakikat hidup. Selain itu, semua ilmu memiliki fungsi serupa dalam wilayah empirik dan alat untuk memahami realitas kehidupan. Oleh karena itu, walaupun bermacam-macam disiplin ilmu tidak menunjukan keterpisahan, tetapi hanya pengklasifikasian ilmu saja sebab hakekatnya sumber ilmu semua dari Allah SWT.

Metafora velg roda dengan berbagai komponennya persis seperti ciri dan fungsi ilmu tadi. Jari-jari roda ibarat sejumlah disiplin ilmu yang menopang hakekat hidup yang berada pada lingkaran bagian dalam kehidupan kita. Begitu juga, kajian dalam beragam disiplin ilmu dapat menyentuh kehidupan nyata yang berada pada lingkaran luar kehidupan manusia dan alam semesta. Karenanya, ilmu -baik yang berkembang dari ayat-ayat Kawniyyah maupun Qur'aniyyah- berada dalam satu kepemilikan, yakni milik Allah Swt, bersumber dari kehendak-Nya dan dimanfaatkan manusia sebagai fasilitas hidupnya.

Metafora velg ini mencerminkan sikap optimisme bahwa integrasi keilmuan UIN Sunan Gunung Djati Bandung sangat relevan dengan hakikat keterkaitan dan keterikatan ilmu. Ilmu pengetahuan yang satu dengan yang lainnya bekerja sama secara simultan dan holistik guna meno-pang tantangan perkembangan zaman. Disparitas perbedaan dalam satuan wilayah keilmuan UIN Sunan Gunung Djati Bandung yang beraneka warna (colorful) dibanding perguruan tinggi lain yang hanya mengungkap ayat-ayat kawniyyah tidak lagi menjadi bagian dikhotomis dalam implementasi proses pendidikannya.

Selain itu, harapan dan optimisme yang tersirat dalam metapora velg sebuah roda tercermin dari dinamika velg yang berputar. Putaran ini melambangkan bahwa setiap ilmu yang dikembangkan di UIN Sunan Gunung Djati Bandung selalu memperluas cakrawala cakupannya. Ilmu-ilmu itu tidak berhenti pada prestasinya yang telah dicapai saat ini, tetapi secara terus menerus melakukan pembaharuan pada dirinya sesuai dengan perkembangan zaman. Dinamika inilah merupakan titik singgung atau arsiran antar ilmu yang dapat ditemukan secara jelas. Ibarat pergeseran posisi sebuah jari-jari roda yang menyentuh area tempat putaran jari-jari lainnya, ilmu yang satu akan saling mengisi dengan ilmu lainnya atau korelasi.

Ketiga, ban luar yang terbuat dari karet melambangkan realitas kehidupan yang tidak terpisahkan dari semangat nilai-nilai ilahiyah dan gairah kajian ilmu. Pada sisi luar ban ini dilambangkan tiga istilah, yaitu iman, ilmu dan amal shaleh sebagai cita-cita luhur yang menjadi target akhir dari profil lulusan UIN. Kekuatan iman berfungsi sebagai jangkar yang dipancang kokoh dalam setiap pribadi lulusan UIN Sunan Gunung Djati Bandung. Kekuatan iman ditanamkan melalui suatu upaya pendidikan yang komplementer, mencakup berbagai ikhtiar untuk membangun situasi kampus yang ilmiah dan religius. Kekuatan ilmu merupakan basis yang dimiliki UIN Sunan Gunung Djati Bandung yang mencerminkan dinamika kampus sebagai zona pergumulan para ilmuwan dan cendekiawan yang dapat tumbuh subur dengan menaruh harapan besar pada pengembangan ilmu pengetahuan yang melahirkan generasi 'aliman. Indikator kesuburan ilmu pada lulusan tidak hanya diukur oleh ciri-ciri kecerdasan nalar, tetapi juga oleh komitmen dalam menggunakan ilmu sebagai pembimbing tingkah laku yang memiliki AL-Akhlak AL-Karimah.

Sedangkan amal shaleh sebagai wujud perilaku yang terbimbing oleh iman dan ilmu. Seperti halnya iman, ilmu, dan amal shaleh merupakan buah dan proses pendidikan yang dibangun di atas konsep integrasi keilmuan UIN Sunan Gunung Djati Bandung dengan kekuatan energi yang terpancar dari nilai-nilai Ilahi. Amal shaleh para lulusan benar-benar mencitrakan ketauladanan dan dampak yang luas bagi masyarakat yang membutuhkannya. Ibarat sisi luar ban yang menempel pada permukaan bumi, amal shaleh ini akan benarbenar teruji dalam realitas kehidupan nyata.

Dasar pembidangan ilmu yang dikembangkan oleh UIN Sunan Gunung Djati Bandung nantinya berorientasi pada usaha memadukan pertama, hubungan organis semua disiplin ilmu pada suatu landasan keislaman; kedua, hubungan yang integral diantara semua 
disiplin ilmu; ketiga, saling keterkaitan secara holistik semua disiplin ilmu untuk mencapai tujuan umum pendidikan nasional; keempat, keutamaan ilmu pengetahuan yang disampaikan berdasarkan ayat ayat qur'aniyyah dan kawniyyah menjadi landasan pandangan hidup yang menyatu dalam satu tarikan nafas keilmuan dan keislaman; kelima, kesatuan pengetahuan yang diproses dan cara pencapaiannya dikembangkan secara ilmiah akademis; keenam, pengintegrasian wawasan keislaman, kemodernan, dan keindonesiaan dalam spesialisasi dan disiplin ilmu menjadi dasar bagi seluruh pengembangan disiplin akademis. Semua itu diabadikan untuk kesejahteraan manusia secara bersama-sama yang merupakan tiga komponen utama dari peneguhan iman, ilmu, dan amal shaleh. Dengan ungkapan lain, implementasi proses belajar mengajar pada UIN Sunan Gunung Djati Bandung dapat menghasilkan kualifikasi sarjana yang memiliki keagungan al-Akhlak al-Karimah, kearifan spiritual, keluasan ilmu, dan kematangan Profesional.

Setelah kita melihat gambar di atas, kita melihat kemungkinan titik temu antara keduanya. Nantinya lewat temuan-temuan terbarunya, ilmu dapat merangsang agama untuk senantiasa tanggap memikirkan ulang keyakinan $\neg$ keyakinannya secara baru dan dengan begitu menghindarkan agama itu sendiri dari bahaya stagnasi dan pengaratan. Di samping temuan-temuan IPTEK pun dapat memberi peluang baru bagi agama untuk makin mewujudkan konsep-konsepnya secara nyata, di sini letaknya peran wahyu memandu ilmu.

Pada dasarnya, ilmu pengetahuan manusia secara umum hanya dapat dikategorikan menjadi tiga wilayah pokok: Natural Sciences, Social Sciences, dan Humanities. Oleh karenanya, untuk pemberian sebuah universitas, Departemen Pendidikan Nasional mensyaratkan dipenuhi-nya 6 program studi umum dan 4 program studi sosial. Persyaratan ini bagus, tetapi para ilmuwan sekarang mengeluh tentang output yang dihasilkan oleh model pendidikan universitas yang berpola demikian. Sama halnya keluhan orang terhadap alumni perguruan tinggi agama yang hanya mengetahui soal-soal normatif doktrinal agama, tetapi kesulitan memahami empirisasi agama sendiri, lebih-lebih empirisasi agama orang lain, maka UIN sebagai jawabannya yang tepat.

\section{SIMPULAN DAN SARAN}

\section{A. Simpulan}

Berdasarkan pemaparan pada penelitian ini dapat disimpulkan bahwa UIN Sunan Gunung Djati Bandung (disingkat UIN Bandung) mengusung visi yang jelas dan pasti berbeda (distinct) dengan Perguruan Tinggi yang lain. Kampus UIN juga terus berupaya meningkatkan manajemen dan teknologi sebagai fitur andalan untuk mencapai kualitas Perguruan Tinggi. Institusi ini menggunakan paradigma WMI (Wahyu Memandu Ilmu) sebagai landasan filofisnya, menjadikan visi UIN Bandung menjadi sangat khas dibandingkan dengan yang lain. Perhatikan visi UIN Bandung berikut: Menjadi Universitas Islam Negeri yang Unggul dan Kompetitif Berbasis Wahyu Memandu Ilmu dalam Bingkai Akhlak Karimah di ASEAN tahun 2025. Dengan visi ini, paradigma keilmuan UIN Bandung dan kebijakan pengembangn Perguruan Tinggi bersifat terintegrasi dengan nilai-nilai wahyu (agama), yakni sesuatu yang tidak bersifat parsial atau dikotomis. Paradigma WMI dengan demikian bukan sekedar landasan dalam menetukan arah dan kebijakan lembaga tetapi menjadi pedoman penyelenggaraan Perguruan Tinggi. Pada ranah akademik dimana core bussines-nya menyelenggarakan pendidikan, paradigma tersebut menjadi acuan dalam pembentukan kepribadian dan pengembangan disiplin ilmu.

\section{B. Saran}

Pembahasan terkait penelitian konsep wahyu memandu ilmu sebagai paradigma keilmuan UIN Sunan Gunung Djati dalam penelitian ini masih sangat terbatas dan membutuhkan banyak masukan. Saran untuk penulis selanjutnya adalah mengkaji lebih dalam dan secara komprehensif terkait konsep wahyu memandu ilmu sebagai paradigma keilmuan UIN Sunan Gunung Djati.

\section{DAFTAR RUJUKAN}

Arifudin, O. (2019). Manajemen Sistem Penjaminan Mutu Internal (SPMI) Sebagai Upaya Meningkatkan Mutu Perguruan Tinggi. MEA (Manajemen, Ekonomi, \& Akuntansi), 3(1), 161-169.

Arifudin, 0. (2021). Implementasi Balanced Scorecard dalam Mewujudkan Pendidikan Tinggi World Class. Edumaspul: Jurnal Pendidikan, 5(2), 767-775. 
Bahri, A. S. (2021). Pengantar Penelitian Pendidikan (Sebuah Tinjauan Teori dan Praktis). Bandung: Widina Bhakti Persada.

Bashori. (2017). Paradigma Baru Pendidikan Islam: Konsep Pendidikan Hadhari. Jurnal Penelitian, 2(1), 12-21.

Darmalaksana. (2019). Techno University to increase the quality of islamic higher education in Indonesia. International Journal of Civil Engineering and Technology, 10(1), 1264-1273.

Fathirma'ruf, F., \& M. Said, B. (2020). Pengembangan Perangkat Pembelajaran Konstruktivistik Model Teaching with Analogies (TWA) pada Mata Kuliah Database Management System (DBMS) untuk Meningkatkan Kemampuan Berpikir Kreatif Mahasiwa. Jurnal Teknologi Informasi dan Ilmu Komputer, 7(5), 10511060.

doi:http://dx.doi.org/10.25126/jtiik.20207 52388

Fattah. (2008). Landasan Menejemen Pendidikan. Bandung: Remaja Rosdakarya.

Hanafiah, H. (2021). Pelatihan Software Mendeley Dalam Peningkatan Kualitas Artikel Ilmiah Bagi Mahasiswa. Jurnal Karya Abdi Masyarakat, 5(2), 213-220.

Hasbi, I. (2021). Administrasi Pendidikan (Tinjauan Teori Dan Praktik). Bandung: Widina Bhakti Persada.

Imansyah, M. N., \& Asmedy, A. (2021). Akselerasi covid-19 pada proses pembelajaran di era pendidikan 4.0. JPPI (Jurnal Penelitian Pendidikan Indonesia), 7(2), 279-284.

Irawan. (2019). Kalibrasi Spektrofotometer sebagai Penjaminan Mutu Hasil Pengukuran dalam Kegiatan Penelitian dan Pengujian. Indonesian Journal of Laboratory, 1(2), 1-9.

Irwansyah, R. (2021). Perkembangan Peserta Didik. Bandung : Widina Bhakti Persada.

Juhji. (2020). Manajemen Humas Sekolah. Bandung: Widina Bhakti Persada.
Kuntowijoyo. (2006). Islam Sebagai Ilmu: Epistemologi, Metodologi, dan Etika. Yogyakarta: Tiara Wacana.

Manser. (1991). Oxford Learner's Pocket Dictionary. London: Oxford University Press.

Marantika, N. (2020). Manajemen Humas Sekolah. Bandung: Widina Bhakti Persada Bandung.

Na'im, Z. (2021). Manajemen Pendidikan Islam. Bandung: Widina Bhakti Persada.

Nasrudin. (2008). Humanisme Religius Sebagai Paradigma Pendidikan Islam (Tinjauan Filosofis atas Pemikiran Abdurrahman Mas'ud). Semarang: IAIN Walisongo.

Nasser, A. A. (2021). Sistem Penerimaan Siswa Baru Berbasis Web Dalam Meningkatkan Mutu Siswa Di Era Pandemi. Biormatika: Jurnal Ilmiah Fakultas Keguruan Dan Ilmu Pendidikan, 7(1), 100-109.

Natsir. (2013). Paradigma Wahyu Memandu Ilmu dalam Pembidangan Ilmu-Ilmu Keislaman. Bandung: UIN Sunan Gunung Djati.

Rahayu, Y. N. (2020). Program Linier (Teori Dan Aplikasi). Bandung : Widina Bhakti Persada.

Roqib. (2009). Ilmu Pendidikan Islam: Pengembangan Paradigma Pendidikan Integratif. Yogyakarta: LkiS.

Simamora. (2016). Integrasi Keilmuan Pada Perguruan Tinggi Islam di Kota Medan. Disertasi Universitas Islam Negeri Sumatera Utara.

Suprayogo. (2005). Integrasi Ilmu dan Agama: Interpretasi dan Aksi. Bandung: Mizan.

Tabroni. (2017). Sanksi (Ta'zir) dalam perspektif pendidikan islam: studi tentang pelaksanaan Ta`zîr pada santri di Pondok Pesantren Manba'ul Ulum Kabupaten Cirebon, AlMutawally Kabupaten Kuningan dan Baitul Arqom Kabupaten Bandung. Doctoral thesis UIN Sunan Gunung Djati Bandung. 